\title{
Controlling phase formation during aluminium/steel Nd:YAG laser brazing*
}

\author{
L. Rodriguez ${ }^{* *}$, A. Mathieu***, C. Langlade ${ }^{* * * *}$ and A. Vannes ${ }^{* * * * *}$
}

\begin{abstract}
Abstrac
The reduction of fuel consumption of internal combustion motors, imposed by the new anti-pollution and energy saving laws may be attained by reducing the weight of vehicles, introducing, for example, aluminium sections into the main steel car-body. Laser brazing is a process which can be used to perform such a junction. The main problem of welding this kind of materials combination with conventional processes is the potential formation of inter-metallic phases, which reduces the good performance of the joint. Laser brazing allows a very good control of the thermal development of the joint, with a limited precipitation of these brittle phases. This paper presents the results of a feasibility study made with ZnAl-30 as filler metal. The study shows that the type of configuration used for the assembly has a particular influence on the formation of brittle phases and consequently on the mechanical performance of the joint.
\end{abstract}

Keywords Laser. Brazing. Aluminium. Steel. Welding.

\section{Control de la formación de fases en la soldadura fuerte de Al/Fe mediante haz láser Nd:YAG}

Resumen La reducción en el consumo de combustibles fósiles y las emergentes leyes mundiales anti-contaminación, obligan a prever una reducción en el peso de los vehículos de transporte. Esta condición se puede cumplir por ejemplo, introduciendo componentes de Aluminio en el cuerpo de la carrocería principal de acero de los mencionados vehículos. El principal problema que se presenta al realizar este tipo de ensamblaje es la formación de fases íntermetálicas frágiles que pueden comprometer el buen desenvolvimiento de la unión. La soldadura con rayo láser permite un buen control de calor aportado y una formación muy limitada de este tipo de fases. Este trabajo presenta los resultados preliminares de los estudios realizados en uniones soldadas con ZnAl-30 como material de aportación. El estudio muestra que el tipo de configuración utilizada para realizar la soldadura tiene una influencia importante sobre la posibilidad de formación de estas fases ínter-metálicas.

Palabras clave Soldadura Fuerte. Láser. Aluminio. Acero.

\section{INTRODUCTION}

The imposition of new international anti-pollution and energy saving laws plus the increasing rate of pollution of the environment, requires a reduction in the consumption of fuels, not only of automobiles, but eventually also of all mass transport systems. This objective may be fulfilled by introducing aluminium sections into the main steel body of such vehicles $^{[1 \text { and } 2]}$.

\footnotetext{
* Trabajo recibido el día 13 de febrero de 2006 y aceptado en su forma final el día 1 de junio de 2006.

** LTDS-MMP, Ecole Centrale de Lyon, 36 Av Guy de Collongue, Ecully 69134, France. UNEXPO, Barquisimeto, Venezuela.

$* * *$ Tm - Université Bourgogne, IUT Le Creusot, 12 rue de la Fonderie, France.

$* * * *$ LTDS-MMP, Ecole Centrale de Lyon, 36 Av Guy de Collongue, Ecully 69134, France.
} 
Table I. Typical Composition of 6016 aluminium alloy (Wt\%)

Tabla I. Composición Química de la aleación A-6016 (\% peso)

\begin{tabular}{ccccccccc}
\hline Si & Mg & Fe & Zn & Mn & Cu & Ti & Cr & Rem. \\
\hline $1.0-1.5$ & $0.25-0.6$ & $<0.5$ & $<0.2$ & $<0.2$ & $<0.2$ & $<0.15$ & $<0.1$ & $<0.2$ \\
\hline
\end{tabular}

Table II. Composition of the steel AISI 1020 (WT \%)

Tabla II. Composición Química de la aleación AISI-1020 (\% peso)

\begin{tabular}{ccccccc}
\hline $\mathbf{C}$ & $\mathbf{M n}$ & $\mathbf{P}$ & $\mathbf{S}$ & $\mathbf{S I}$ & $\mathbf{A l}$ & $\mathbf{T i}$ \\
\hline 0.002 & 0.1050 & 0.009 & 0.006 & 0.006 & 0.0340 & 0.0680 \\
\hline
\end{tabular}

It might be more practical, for mechanical and weight reasons, to use structures with a combination of different metals, such as aluminium and steel, for example. These structures may be assembled, either by brazing or soldering, even when the difference in the thermal and metallurgical properties might give reason for concern ${ }^{[3]}$.

A suitable source of energy to join such different materials is the laser beam. The conditions which can be applied to the process allow getting a much localized fusion, with the possibility of automation and perfect control of the quality of the joints ${ }^{[4}$ and 5$]$. Below, we present the results of optical and electron microscope studies and an analysis of the mechanical performance of the brazed joints in contrast to the different levels of the laser power used.

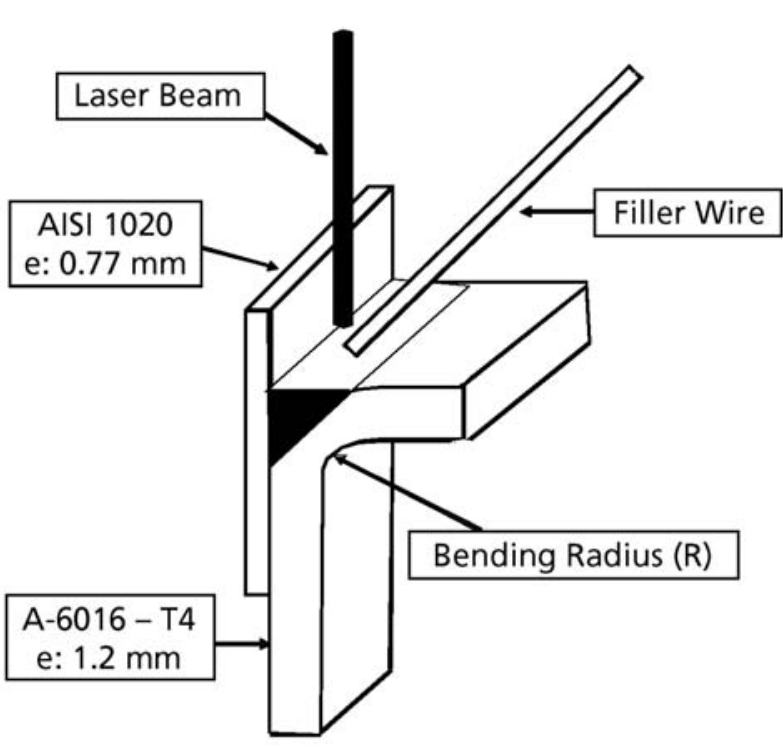

Figure 1. Angle configuration used.

Figura 1. Configuración en ángulo utilizada.

\section{EXPERIMENTAL PROCEDURE}

\subsection{Materials}

The test samples were made of a 6016 T-4 heat-treated aluminium alloy sheet (thickness: $1.2 \mathrm{~mm}$ ), which composition is given in table I; and a ferritic, low carbon steel sheet AISI 1020 (thickness: $0.77 \mathrm{~mm}$ ), which composition is given in table II. Both sides of the steel sheet are dip Zn-galvanized; the thickness of the galvanized coating was in average about $10 \mu \mathrm{m}$.

The difference in melting points and the solubility of iron, aluminium and zinc play an important role in the success of the joining process. This is why the choice of the filler metal is extremely important and the reason for the selection of $\mathrm{ZnAl}-15$ (85 wt \% $\mathrm{Zn}+15$ $\% \mathrm{wt} \mathrm{Al}$ ) for that purpose, with a melting temperature of $430^{\circ} \mathrm{C}$. The wire feeding speed is usually the

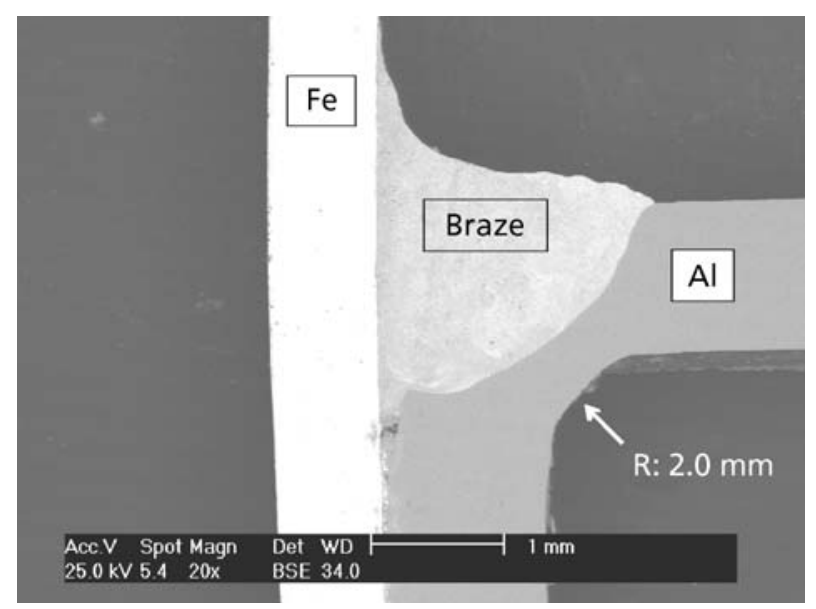

Figure 2. Profile of Brazing with bending radius of $2.0 \mathrm{~mm}$.

Figura 2. Perfil de soldadura en pieza con 2,00 mm de radio de doblado. 
CONTROLLING PHASE FORMATION DURING ALUMINUM/STEEL ND:YAG LASER BRAZING CONTROL DE LA FORMACIÓN DE FASES EN LA SOLDADURA FUERTE DE AL/FE MEDIANTE HAZ LÁSER ND:YAG

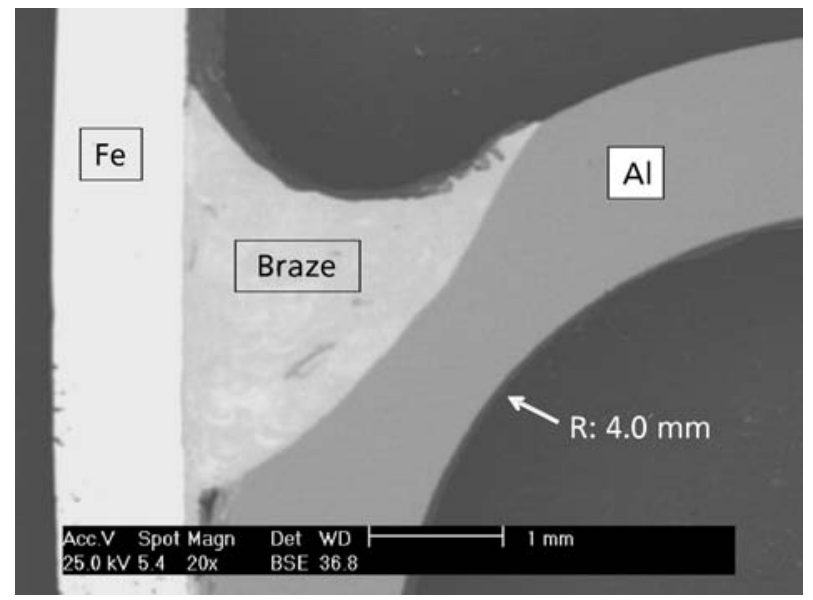

Figure 3. Profile of Brazing with bending radius of $4.0 \mathrm{~mm}$.

Figura 3. Perfil de soldadura en pieza con 4,00 $\mathrm{mm}$ de radio de doblado.

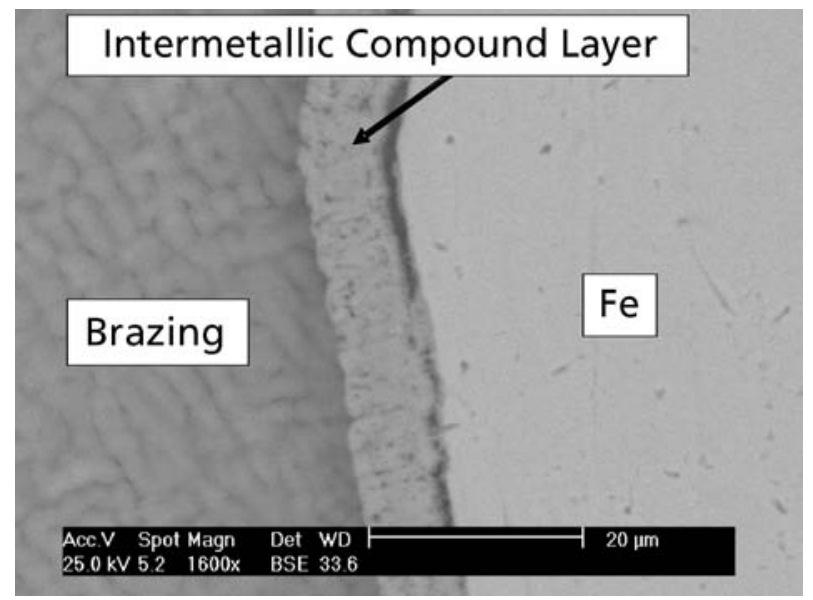

Figure 4. Intermetallic Compound Layer between Fe and Brazing.

Figura 4. Capa de compuestos intermetálicos entre cordon y el acero.

same as that of the advancement of the work-piece during the brazing, that is between 1.0 and $3.0 \mathrm{~m} / \mathrm{min}$

\subsection{LASER SYSTEM AND JOINT CONFIGURATION}

The heat source used is a TRUMPF (HL 3006D) continuous Nd: YAG laser, with a maximum power of 3.0 $\mathrm{kW}$, pumped by lamps. The beam is transmitted to the surface of the target via a light cable of $600 \mu \mathrm{m}$ diameter. The laser spot is circular in shape with a uniform intensity profile, typical of the classical optical arrangement associated with a collimating lens and a focussing lens of $200 \mathrm{~mm}$ focal length. The translation of the assembly is ensured made by a numeri-

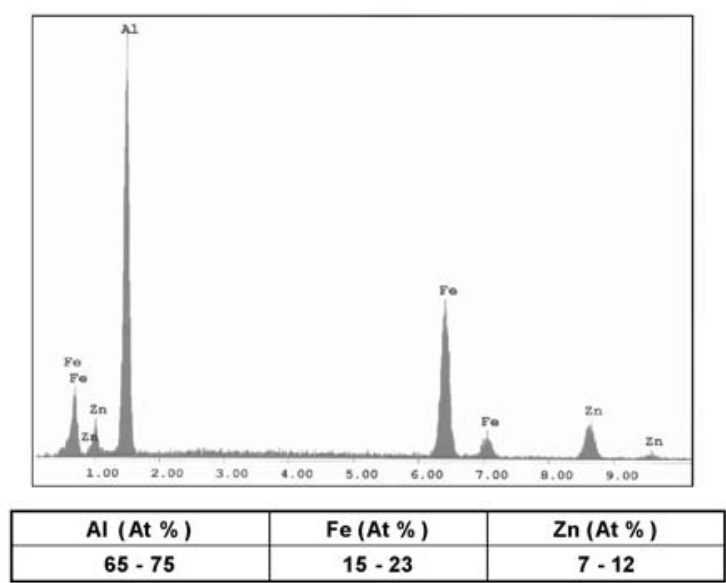

Figure 5. EDX analysis and average values of chemical composition of intermetallic layer.

Figura 5. Análisis EDX y composición química average de la capa de intermetálicos.

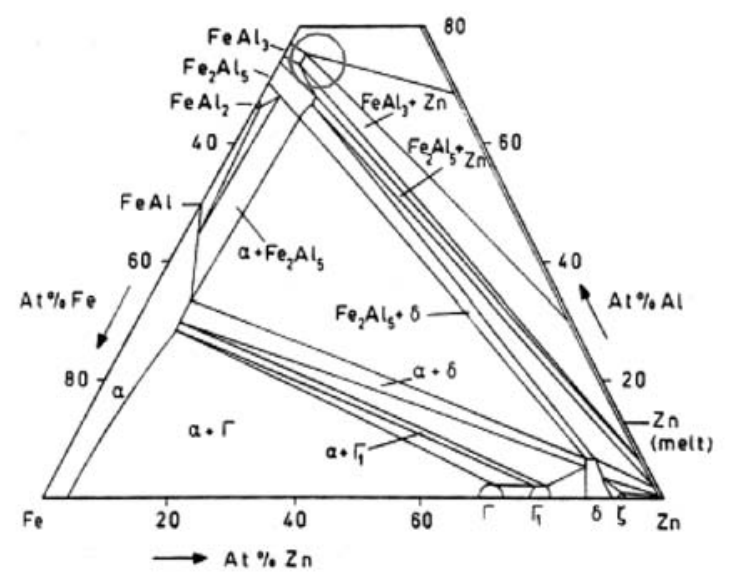

Figure 6. Fe-Zn-Al Diagramme at $450{ }^{\circ} \mathrm{C}$ [9-11].

Figura 6. Diagrama Fe-Zn-Al a $450^{\circ} \mathrm{C}$.

cally controlled 4-axis machine. The laser power was varied between 1.0 and $3.0 \mathrm{~kW}$.

For the present study two different angle joint configurations were used (Fig. 1). The aluminium plate was bent at $90^{\circ}$ with two different bending radii, which were $4.0 \mathrm{~mm}$ and $2.0 \mathrm{~mm}$ respectively. The shielding gas used during brazing was ARCAL $37^{\circ}$ (70\% Helium + $30 \%$ Argon), which was applied behind the interaction zone via a $10 \mathrm{~mm}$ diameter tube. The gas flow was set to be $20 \mathrm{l} / \mathrm{min}$.

\section{EXPERIMENTAL RESULTS}

\subsection{Macro and microstructures}

Figures 2 and 3 show the macroscopic cross section of the brazed joints. A significant difference can be 


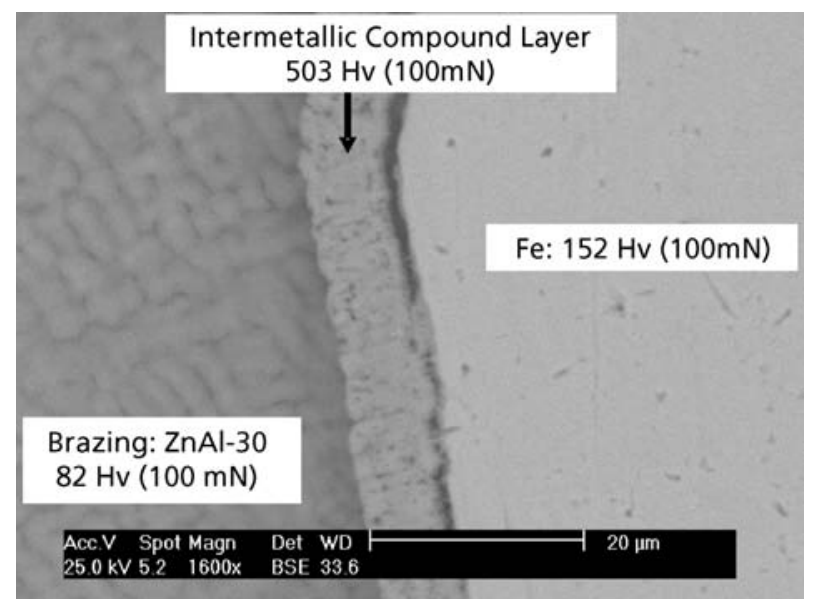

Figure 7. EDX analysis and average values of chemical composition of intermetallic layer.

Figura 7. Valores de Microdureza en capa de intermetálicos.

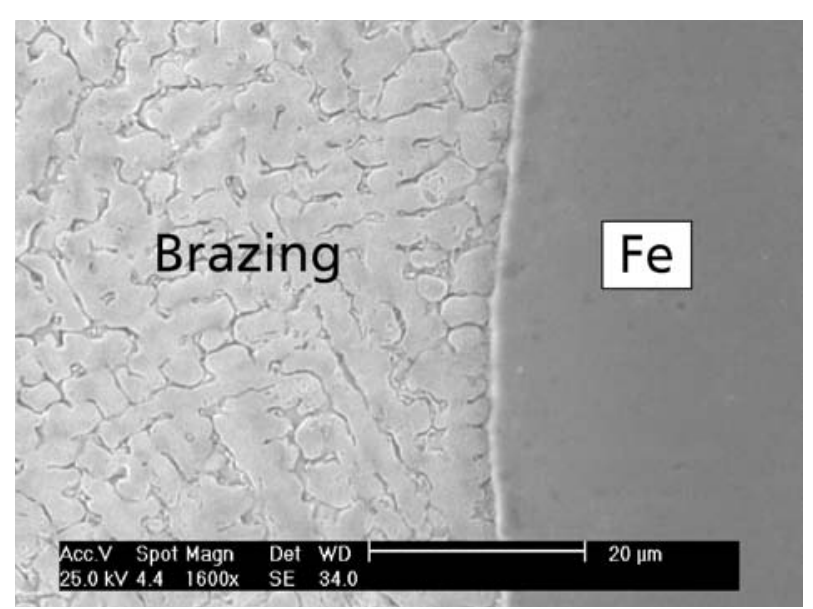

Figure 8. Absence of Intermetallic layer in samples with bending radius of $4.0 \mathrm{~mm}$.

Figura 8. Ausencia de intermetálicos en probetas con un radio de doblado de $4,0 \mathrm{~mm}$.

observed in the brazing surfaces produced in the joints. For the same brazing parameters, the fulfilled brazing area for the configuration with a bending radius of $2.0 \mathrm{~mm}$ (Fig. 2) is larger than the one obtained for the configuration with a bending radius of $4.0 \mathrm{~mm}$ (Fig. 3). This fact will have an important effect on the mechanical performance of the joint, as can be seen further in this work.

Scanning electron microscopy revealed the presence of a layer of intermetallic compounds (Fig. 4) at the interface between the steel sheet and the brazing tiller in the joints made with the configuration with a bending radius of $2.0 \mathrm{~mm}$, for all power levels applied with the laser beam.

The average values of the chemical composition of these layers can be seen in figure 5. This makes us

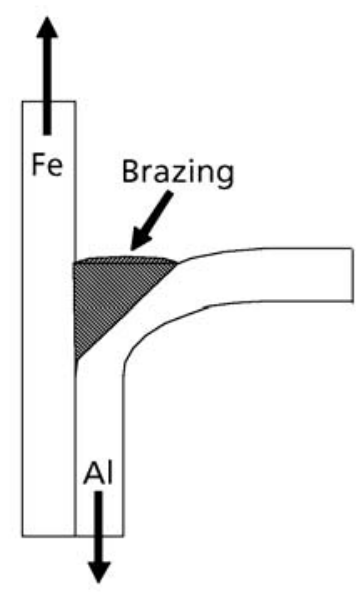

Figure 9. Set up of tensile test applied on the simples.

Figura 9. Ensayo de tracción aplicado a las probetas.

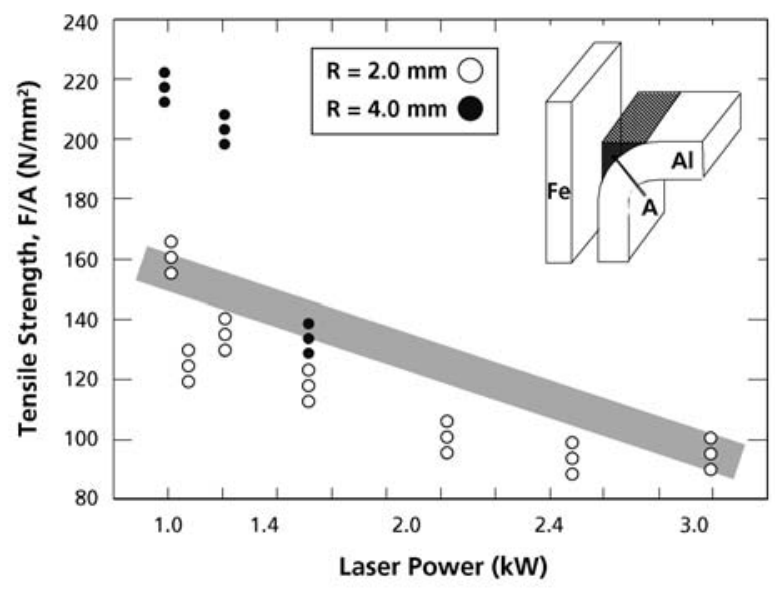

Figure 10. Tensile strength related to Laser Power and bending radius of simples.

Figura 10. Resistencia a la tracción relacionada a la potencia del láser.

assume the presence of phases of the type $\mathrm{Fe}_{\mathrm{x}} \mathrm{Al}_{\mathrm{y}}$, especially $\mathrm{Fe}_{2} \mathrm{Al}_{5}+\mathrm{Zn}$ and $\mathrm{FeAl}_{3}+\mathrm{Zn}$ (see diagram in figure 6).

Micro Hardness tests (100 mN) were also made on the interaction layer, with the resulting average hardness values shown in figure 7 . The presence of this layer of intermetallic compounds at the interface steel/seam was not observed in joints made with the configuration with a bending radius of $4.0 \mathrm{~mm}$ for a laser power less than $1100 \mathrm{~W}$ (Fig. 8).

These differences in the formation of the layer of intermetallic compounds for these two configurations may be based on the different level of heating experienced on the steel side, due to the reflection of the laser on the aluminium sheet during the brazing process. In the case of the configuration with a higher bending radius $(4.0 \mathrm{~mm})$, the laser beam hits the 
CONTROLLING PHASE FORMATION DURING ALUMINUM/STEEL ND:YAG LASER BRAZING CONTROL DE LA FORMACIÓN DE FASES EN LA SOLDADURA FUERTE DE AL/FE MEDIANTE HAZ LÁSER ND:YAG

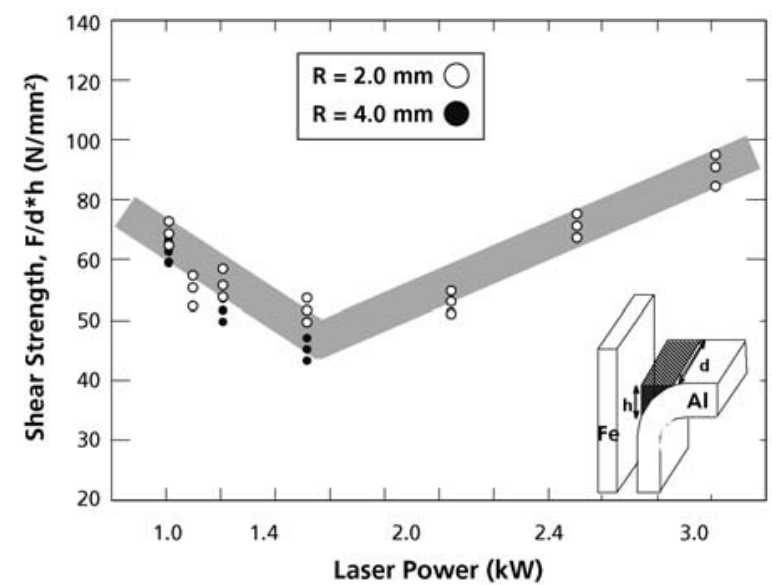

Figure 11. Shear strength related to Laser Power and bending radius of simples.

Figura 11. Resistencia a la cizalladura relacionada a la potencia del laser.

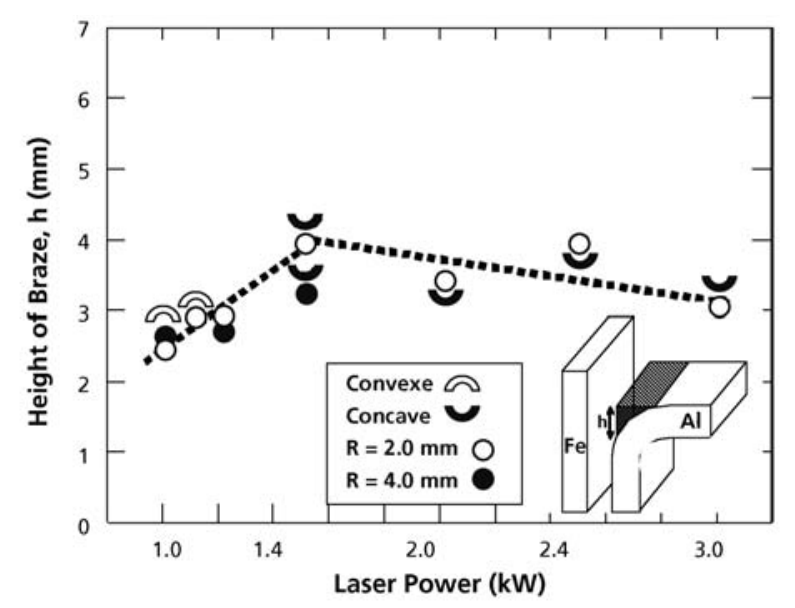

Figure 12. Change of height of braze related to laser power.

Figura 12. Altura del cordón con respecto a la potencia del láser.

aluminium sheet farther from the steel surface and the reflection against it will produce a less important heating. On the other side, the impact of the laser of the aluminium sheet with a bending radius of 2.0 $\mathrm{mm}$ is closer to the steel side, producing a very important heating on its surface due to the reflection of the beam.

\subsection{Mechanical properties of the joint}

Figure 9 shows the set up of the tensile tests performed on the brazed samples. The joints broke generally at the interface Fe/braze, probably due to the presence of the brittle compounds ${ }^{[9-11]}$ and also due to the fact that this kind of tensile tests produce a localized com-

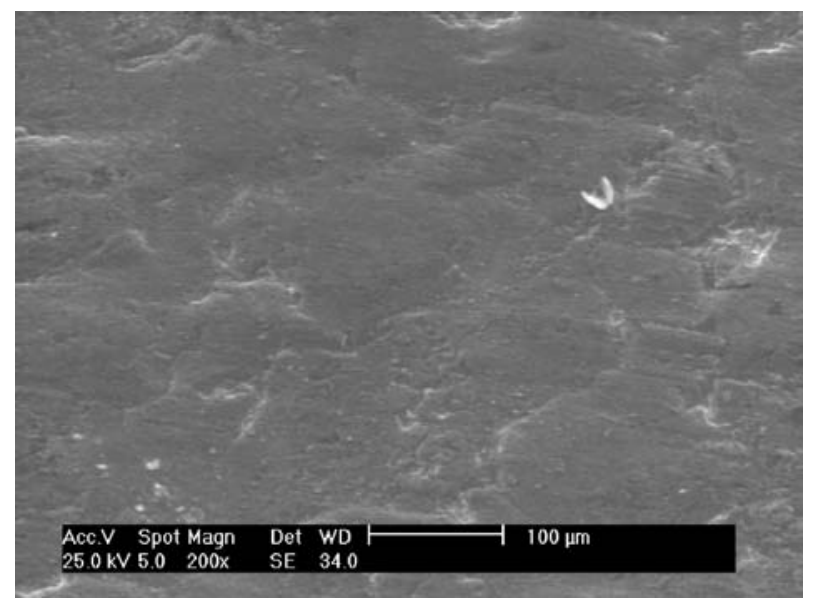

Figure 13. Shear fracture surface of a joint made with a bending radius of $2.0 \mathrm{~mm}$.

Figura 13. Aspecto de la fractura para una probeta con radio de doblado de $2,00 \mathrm{~m}$.

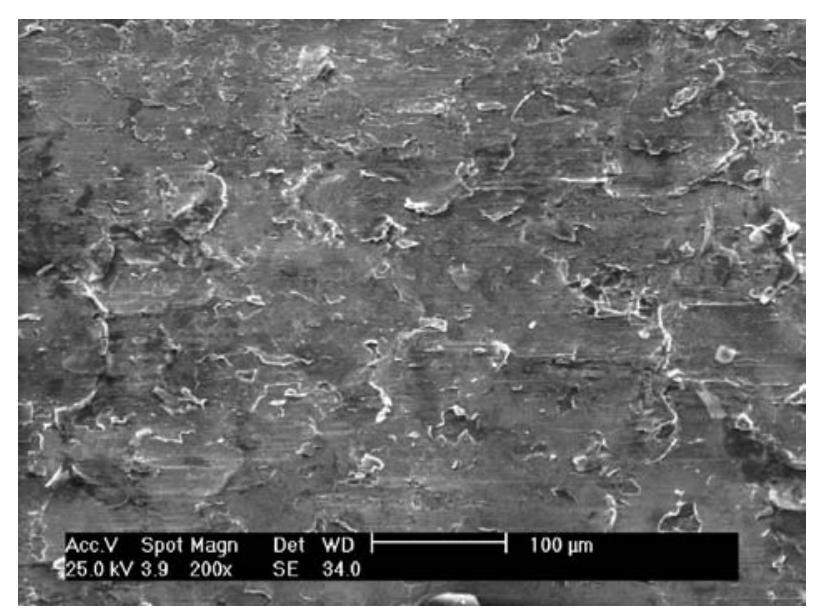

Figure 14. Shear fracture surface of a joint made with a bending radius of $4.0 \mathrm{~mm}$.

Figura 14. Aspecto de la fractura para una probeta con radio de doblado de 4,00 $\mathrm{m}$.

bination of shearing and tensile solicitation at this interface.

The values of the tensile strength of the joints for the two different radiuses of bending are shown as a function of the laser power in figure 10 (each point represents the average value of three tested samples and $\hat{U}$ the dispersion). The values for the joints made with the bending radius of $4.0 \mathrm{~mm}$ are higher than those obtained in the joints made with a bending radius of $2.0 \mathrm{~mm}$, for the same level of laser power. This is due probably to the higher brazing surface obtained in the samples with a lower bending radius.

Figure 11 shows the values of the shear strength obtained in the specimens as a function of the laser power and bending radius (each point represents again 


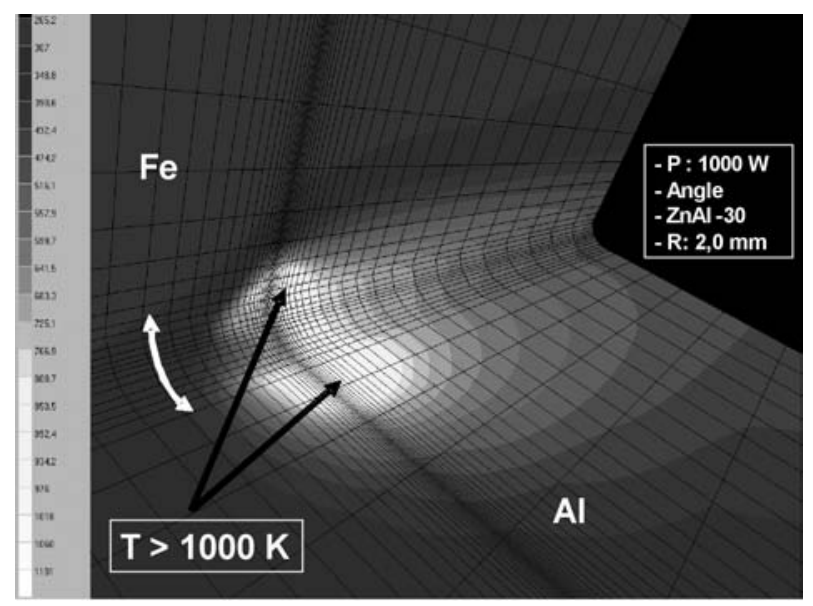

Figure 15. Temperature spectrum for samples with bending radius $2.0 \mathrm{~mm}$.

Figura 15. Espectro de temperatura para probetas con radio de curvatura de $2,0 \mathrm{~mm}$.

the average value of three tested samples and $\hat{U}$ the dispersion).

It is important to notice the presence of a breaking point in the curve at $1200 \mathrm{~W}$ of the laser power; this might be due to the change observed in the height of the seams with increasing laser power (Fig. 12), probably due to the stronger reflection of the laser beam on the Aluminum plate against the Steel plate..

In this case the values for the joints made with the bending radius of $2.0 \mathrm{~mm}$ are higher than those obtained in the joints made with a bending radius of 4.0 $\mathrm{mm}$, for the same level of laser power. This is probably due to the higher shear-surface obtained in the joints with a lower bending radius (Fig. 12)

Figure 13 shows the shear fracture surface of a joint made with a bending radius of $2.0 \mathrm{~mm}$. It can be seen that the fracture presented in this case is totally smooth, typical of a brittle fracture, probably due to the fact that the breaking occurred at the layer of compounds. On the other hand, figure 14 shows that in the case of the shear fracture surface of a joint made with a bending radius of $4.0 \mathrm{~mm}$, some degree de ductility can be observed, probably due to the absence of the layer of compounds.

\subsection{Element finite analysis}

The two configurations were analyzed with a Finite Element Program in order to observe the evolution of the temperature in the brazing zone during the brazing procedure. Figure 15 shows the result of the analysis made to the joints with a bending radius of $2.0 \mathrm{~mm}$ and $1000 \mathrm{~W}$ of laser power. As can be seen for the same brazing parameters, using this configura-

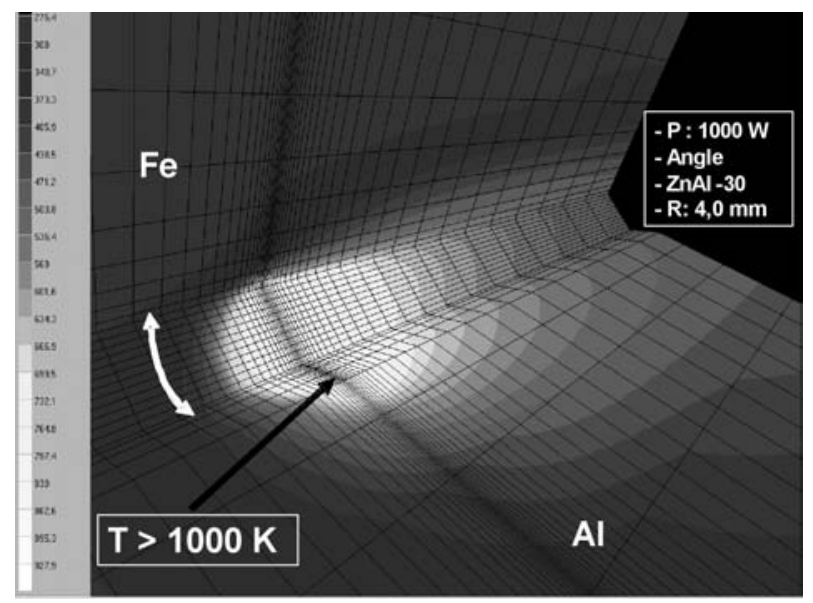

Figure 16. Temperature spectrum for samples with bending radius $4.0 \mathrm{~mm}$.

Figura 16. Espectro de temperatura para probetas con radio de curvatura de $4,0 \mathrm{~mm}$.

tion allows getting a relative high temperature at the steel side, which might be responsible for the production of the layer of inter-metallic compounds. On the other hand, figure 16 shows the result of the analysis made to the joints with a bending radius of $4.0 \mathrm{~mm}$ and $1000 \mathrm{~W}$ of laser power. This last configuration allows having a better control of the temperature at the steel side, which might even avoid the formation of inter-metallic compounds.

\section{CONCLUSIONS}

Heterogeneous brazed joints were produced using a continuous Nd:YAG laser between A-6016 and AISI 1020 (galvanized with $\mathrm{Zn}$ ) as base material and ZnAl15 as filler metal.

The type of configuration used for the brazing might have a potential influence on the formation of compounds at the steel/braze interface.

A compromise should be found between the possibility of getting a joint without the formation of compounds, but with a low brazing surface, and the possibility of getting a higher brazing surface, but with the potential formation of inter-metallic composites.

The mechanical properties of the steel/aluminium assemblies attained a tensile strength of $200 \mathrm{MPa}$. It should be noted that in all cases the values of the tensile strength are sufficient to cover all possible loads on the assemblies.

\section{Aknowledgements}

The authors would like to thank the partners of the A3FL project (Steel/Aluminium Assemblies by Laser 
Beam) in which all the work presented in this article originated. We thank particularly our industrial partners: RENAULT, ALCAN-PECHINEY and ARES for their support.

\section{REFERENCES}

[1] E. Schubert, M. Klassen, I. Zerner, C. WAlZ AND G. Sepold, J. Mat. Proc. Technol. 115 (2001) 2-8.

[2] E. Schubert, I. Zernet and G. SEPOld, Proc. SPIE, Vol. 3097,1997, pp 212-220.

[3] N. Karube, Y. NAKATA AND A. MORI, 25 th ISATA, Italy, 1992 , pp. 119-138.

[4] F. Wagner, I. Zerner, M. Kreimeyer and G. SEPOld, ICALEO, Florida, USA, 2001, pp. 1301.
[5] R. Imhoff, K. Behler, E. Beyer And D. MAISCHNER, 25 th ISATA, Italy, 1992, p. 93.

[6] J. MAZunder, $A S M$ - Handbook, Vol VI , USA, 1990, pp. 254-261.

[7] J. Weston, A. Jones And R. Wallach, $\sigma^{\text {th }}$ Int. Conf. Welding and melting by electron and laser beams, France, 1998, p. 187.

[8] M. NAEM, $6^{\text {th }}$ Int. Conf. Welding and Melting by Electron and Laser Beams, France ,1998, p. 171.

[9] H. SHAHVERd, M. GHOMEShChI, S. SHABESTARI AND J. Hejazi, J. Mat. Proc. Technol. 124 (2002) 345352.

[10] K. Bouché, F. BArbier And A. Coulet, Mat. Sci. Eng. A 249 (1998) 167-175.

[11] S. Kobayashi AND T. YaKou, Mat. Sci. Eng. A 238 (2002) 44-53. 